\title{
Role of high mobility group box-1 and protection of growth hormone and somatostatin in severe acute pancreatitis
}

\author{
Y.F. Wang ${ }^{1 *}$, M. Wu ${ }^{2 *}$, B.J. Ma ${ }^{1}$, D.A. Cai ${ }^{1}$ and B.B. Yin ${ }^{1}$ \\ ${ }^{1}$ Department of Surgery, Huashan Hospital, Fudan University, Shanghai, China \\ ${ }^{2}$ Department of Surgery, Jinshan Pavilion Forest Hospital, Shanghai, China
}

\begin{abstract}
In this study, we investigated the potential role of high-mobility group box 1 (HMGB1) in severe acute pancreatitis (SAP) and the effects of growth hormone $(G)$ and somatostatin (S) in SAP rats. The rats were randomly divided into 6 groups of 20 each: sham-operated, SAP, SAP + saline, SAP + G, SAP + S and SAP + G + S. Ileum and pancreas tissues of rats in each group were evaluated histologically. HMGB1 mRNA expression was measured by reverse transcription-PCR. Levels of circulating TNF- $\alpha$, IL-1, IL-6, and endotoxin were also measured. In the SAP group, interstitial congestion and edema, inflammatory cell infiltration, and interstitial hemorrhage occurred in ileum and pancreas tissues. The levels of HMGB1, TNF- $\alpha$, IL-1, IL-6 and endotoxin were significantly up-regulated in the SAP group compared with those in the sham-operated group, and the 7-day survival rate was $0 \%$. In the $S A P+G$ and $S A P+S$ groups, the inflammatory response of the morphological structures was alleviated, the levels of HMGB1, TNF- $\alpha$, IL-1, IL-6, and endotoxin were significantly decreased compared with those in the SAP group, and the survival rate was increased. Moreover, in the SAP + G + S group, all histological scores were significantly improved and the survival rate was significantly higher compared with the SAP group. In conclusion, HMGB1 might participate in pancreas and ileum injury in SAP. Growth hormone and somatostatin might play a therapeutic role in the inflammatory response of SAP.
\end{abstract}

Key words: Severe acute pancreatitis; High-mobility group box 1; Growth hormone; Somatostatin; Inflammatory response

\section{Introduction}

Acute pancreatitis is a necrotic and inflammatory process that suddenly occurs in peripheral and internal regions of the pancreas (1). Approximately $20 \%$ of patients with acute pancreatitis may develop a more severe form with occurrence of organ dysfunction, which is known as severe acute pancreatitis (SAP) (2). SAP is characterized by the development of a systemic inflammatory response syndrome (SIRS) and multiple organ dysfunction syndrome (MODS) as well as local pancreatic complications, and is associated with a mortality rate of $15-30 \%$, despite continuing improvement in clinical care $(3,4)$. MODS and complications of infection, such as pancreatic necrosis and sepsis, contribute to the increased mortality of SAP $(5,6)$. Meanwhile, the release of inflammatory mediators, including tumor necrosis factor (TNF), interleukin (IL)-1, IL-8, and other inflammatory cytokines, is the primary cause of SIRS and MODS (1).
High-mobility group box 1 (HMGB1), a large group of low-molecular-weight ( $\sim 30 \mathrm{kDa})$ nucleoproteins, belongs to the largest and best characterized group of nonhistone chromosomal proteins (7). It was originally identified as a DNA-binding protein possessing potent proinflammatory properties (8). Subsequently, it has been demonstrated that HMGB1 is actively secreted by live inflammatory cells, such as stimulated macrophages and monocytes, and is released passively from necrotic or damaged cells (9). In addition, proinflammatory cytokines, such as TNF- $\alpha$, IL-1 $\beta$, IL-6, and HMGB1, are thought to have a crucial role in the pathogenesis of acute pancreatitis $(10,11)$. In SAP, HMGB1 has been reported to be involved in SIRS as a cytokine downstream of the inflammatory factors TNF- $\alpha$ and IL-1 $\beta$ (1). Furthermore, the serum HMGB1 level is significantly increased in patients with SAP, and the increase is correlated with disease severity (6). Recently,

Correspondence: B.B. Yin, No. 12 Wulumuqi Zhong Road, Shanghai 200040, China. E-mail: baobingyinbby@hotmail.com

${ }^{*}$ These authors contributed equally to this study.

Received December 3, 2013. Accepted May 27, 2014. First published online September 12, 2014. 
HMGB1 has been shown to be a key mediator of inflammation and organ failure in SAP (12).

Although SAP is characteristic of a serious pathogenic condition with high mortality, and numerous studies have emphasized the important role of proinflammatory cytokines in SAP-related conditions, such as SIRS and MODS, and even death, there have still been no breakthroughs in SAP treatment (13). Growth hormone is produced by the anterior pituitary to stimulate cell proliferation and tissue regeneration in the gastrointestinal tract and pancreas (14). It is also able to modulate cytokine production by subpopulations of inflammatory cells (15). At present, growth hormone is thought to protect intestinal barrier integrity, and to stimulate production of insulin-like growth factor 1 (IGF-1), which can inhibit the development of acute pancreatitis (16).

Somatostatin, recently discovered as an endogenous neuropeptide, has multiple modulatory effects on the immune system. The distribution of specific somatostatin receptor might partially explain the heterogeneity of effects of somatostatin or its analogs on immunocytes (17), which are responses to autocrine and paracrine modes of action. Moreover, somatostatin (or cortistatin) produced by activated cells may interact with other cells expressing the receptors (17). A randomized study found somatostatin could alleviate the inflammatory response, up-regulate cell immune function, and improve the condition of patients with SAP (18).

Therefore, the objective of this study was to examine whether HMGB1 is differentially expressed in SAP and to investigate the effects of growth hormone and somatostatin on the expression of HMGB1 and the severity of pancreas and ileum injury in an experimental SAP model.

\section{Material and Methods}

\section{Chemicals and other reagents}

Sodium taurocholate was obtained from Sigma Chemical Co. (USA). Dimethylformamide and paraformaldehyde were obtained from Sino-American Bio-Tech Inc. (China). The primers were synthesized by the Institute of Cell Biology, Shanghai Institutes for Biological Sciences (SIBS), and the Chinese Academy of Science. Growth hormone and somatostatin were purchased from Laboratoires Serono S.A. (Switzerland). Endotoxin detection kits were purchased from Shanghai Institute of Medical Chemistry (China), enzyme-linked immunosorbent assay (ELISA) kits from T\&B Co. (USA), and Trizol was obtained from Invitrogen Inc. (USA). We prepared sodium taurocholate $(3.5 \%)$.

\section{Animal model and grouping}

Male Sprague-Dawley rats weighing 280 to $320 \mathrm{~g}$ were obtained from the Experimental Animal Center of Chinese Academy of Science. Rats were housed in individual cages, and maintained at $20 \pm 2{ }^{\circ} \mathrm{C}$ and a 12-h light/dark cycle for at least 1 week to acclimate to the surroundings. They were fasted overnight before experiments, but had free access to water. The procedure for animal surgery was performed in accordance with the guidelines of the Animal Care and Use Committee of Chinese Academy of Science, and every effort was made to minimize the number of animals used and their suffering.

The rats were randomly divided into six groups of 20 rats each: i) sham-operated group, not injected with anything; ii) SAP group, 3.5\% sodium taurocholate injected into pancreatic duct (19) (2.5 mL/kg; injection pressure, 3.4-

Table 1. Scoring criteria of pancreatic pathology in rats.

\begin{tabular}{llccc}
\hline Score & \multicolumn{1}{c}{ Edema } & $\begin{array}{c}\text { Inflammatory cells infiltration } \\
\text { (number/high magnification) }\end{array}$ & $\begin{array}{c}\text { Necrosis (number/ } \\
\text { high magnification) }\end{array}$ & Hemorrhage \\
\hline 0 & 0 & 0 & 0 & 0 \\
1 & $\begin{array}{l}\text { Interlobular septal } \\
\text { focal dilation }\end{array}$ & $1-10$ & $1-4$ & 1 \\
2 & $\begin{array}{l}\text { Interlobular } \\
\text { septal widely dilated }\end{array}$ & $11-20$ & $5-10$ & $11-16$ \\
3 & $\begin{array}{l}\text { Alveolar septal } \\
\text { expansion } \\
\text { Cell spacing } \\
\text { expansion }\end{array}$ & $21-30$ & $>16$ & \\
4 & $>30$ or microabscess formation & & \\
\hline
\end{tabular}

Edema score: 0 = null; 1 = interlobar space broadened mildly; 2 = interlobar space broadened severely; 3 = interacinous space broadened; 4 = intercellular space broadened. Inflammatory cell infiltration: the number of leucocytes in lobule and around blood vessels was counted in high-power field; score $0=0-1$; $1=2-10 ; 2=11-20 ; 3=21-30 ; 4=$ more than 30 or microabscess appeared. Necrosis score: $0=$ null; $1=1-10 \%$ necrosis area; $2=11-20 \%$ necrosis area; $3=21-30 \%$ necrosis area; $4=$ more than $30 \%$ necrosis area. Hemorrhage score: $0=$ negative; $1=$ positive. The total of 4 scores listed above was the final score of pancreas injury. Five fields of each section were calculated, and the average score of these 5 fields was the pathological injury score of this section. 


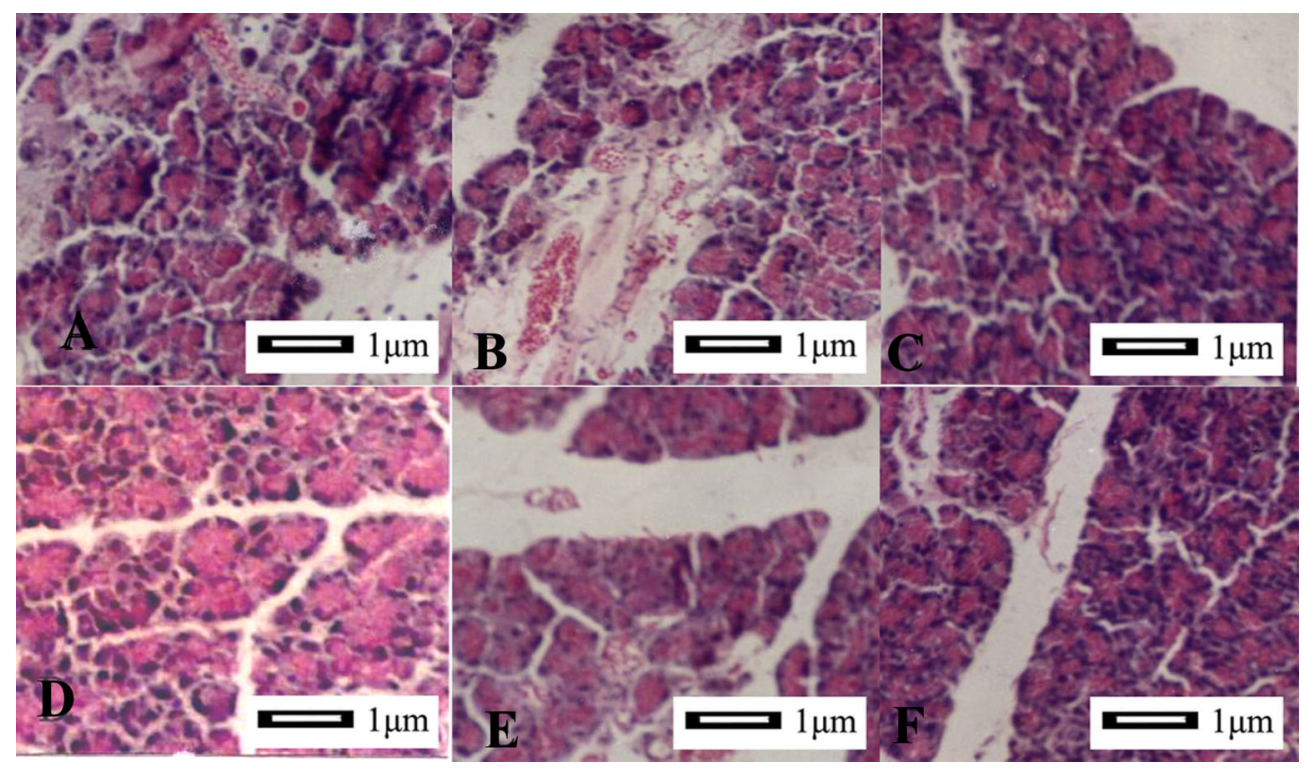

Figure 1. Morphometric analysis of pancreatic tissue $(40 \times)$. A, SAP group, necrosis and hemorrhage were observed in half of the samples. After $24 \mathrm{~h}$, the interstitial pancreatic tissue was significantly widened and the lobular gap was increased. There was great inflammatory cell infiltration and focal or patchy necrosis of pancreas under a light microscope. B, SAP + NS group, pathological changes were the same as those in the SAP group. $C$, Sham-operated group, no necrosis or hemorrhage was found, and the pancreas morphological structure appeared normal. $D, S A P+G+S$ group, edema and inflammatory cell infiltration were found occasionally, and there was a significant difference compared to the SAP group. $E$, SAP $+G$ group, and $F$, SAP $+S$ group, although inflammatory changes were still visible, inflammatory response was attenuated compared to the SAP group. The images were obtained from at least three experiments. SAP: severe acute pancreatitis; NS: normal saline; G: growth hormone; S: somatostatin.

$3.9 \mathrm{kPa}$ ); iii) SAP + NS group, after injection of $3.5 \%$ sodium taurocholate, rats were injected with an equal volume of normal saline (injection pressure, 1.3-1.4 kPa); iv) SAP + G group, $1 \mathrm{~h}$ after injection of $3.5 \%$ sodium taurocholate, $0.5 \mu \mathrm{g} \cdot \mathrm{kg}^{-1} \cdot \mathrm{d}^{-1}$ growth hormone (G) was injected under the skin; v) SAP + S group, $1 \mathrm{~h}$ after injection of $3.5 \%$ sodium taurocholate, $84 \mu \mathrm{g} \cdot \mathrm{kg}^{-1} \cdot \mathrm{d}^{-1}$ somatostatin (S) was injected by femoral vein puncture; vi) SAP $+\mathrm{G}+\mathrm{S}$ group, $1 \mathrm{~h}$ after injection of $3.5 \%$ sodium taurocholate, $0.5 \mu \mathrm{g} \cdot \mathrm{kg}^{-1} \cdot \mathrm{d}^{-1} \mathrm{G}$ was injected under the skin and $84 \mu \mathrm{g} \cdot \mathrm{kg}^{-1} \cdot \mathrm{d}^{-1} \mathrm{~S}$ was injected by femoral vein puncture. After being treated for
$24 \mathrm{~h}$, rats were sacrificed, and the pancreas and ileum were removed. A portion of the tissues was post-fixed in $4 \%$ paraformaldehyde for an additional $24 \mathrm{~h}$, and then transferred to $75 \%$ alcohol for hematoxylin and eosin (HE) staining. A portion of the tissues was post-fixed in electron microscopy preservation solution for electron microscopic observation. The other tissues were stored at $-20^{\circ} \mathrm{C}$ for reverse transcription-PCR (RT-PCR).

\section{RNA extraction and RT-PCR analysis}

Total RNA was extracted from fresh pancreas tissue

Table 2. Pancreatic pathology score comparison in rats.

\begin{tabular}{|c|c|c|c|c|}
\hline Group ( $n=10 /$ group) & Edema & $\begin{array}{l}\text { Inflammatory } \\
\text { infiltration }\end{array}$ & Hemorrhage & Necrosis \\
\hline Sham-operated & 0 & 0 & 0 & 0 \\
\hline SAP & $2.6 \pm 0.96^{* *}$ & $3.0 \pm 0.94^{\star *}$ & $0.8 \pm 0.42^{\star *}$ & $3.2 \pm 1.03^{* *}$ \\
\hline $\mathrm{SAP}+\mathrm{NS}$ & $2.7 \pm 1.06^{\star *}$ & $3.2 \pm 1.03^{\star *}$ & $0.8 \pm 0.43^{* *}$ & $3.1 \pm 1.10^{* *}$ \\
\hline$S A P+S$ & $1.8 \pm 0.63^{\star \# \#}$ & $2.1 \pm 0.88^{\star \# \#}$ & $0.6 \pm 0.51^{*}$ & $2.0 \pm 0.67^{\star \#}$ \\
\hline$S A P+G$ & $2.0 \pm 0.81^{*}$ & $2.3 \pm 1.05^{\star \#}$ & $0.6 \pm 0.52^{*}$ & $2.4 \pm 0.83^{*}$ \\
\hline$S A P+S+G$ & $1.3 \pm 0.48^{\star \# \#}$ & $1.6 \pm 0.70^{\star \# \# ~}$ & $0.4 \pm 0.51^{* \#}$ & $1.4 \pm 0.70^{\star \# \#}$ \\
\hline
\end{tabular}

Data are reported as means \pm SD. SAP: severe acute pancreatitis; NS: normal saline; G: growth hormone; $\mathrm{S}$ : somatostatin. ${ }^{*} \mathrm{P}<0.05$ and ${ }^{* *} \mathrm{P}<0.01$ compared to sham-operated group; ${ }^{*} \mathrm{P}<0.05$ and ${ }^{\# \#} \mathrm{P}<0.01$ compared to SAP group (one-way ANOVA). 

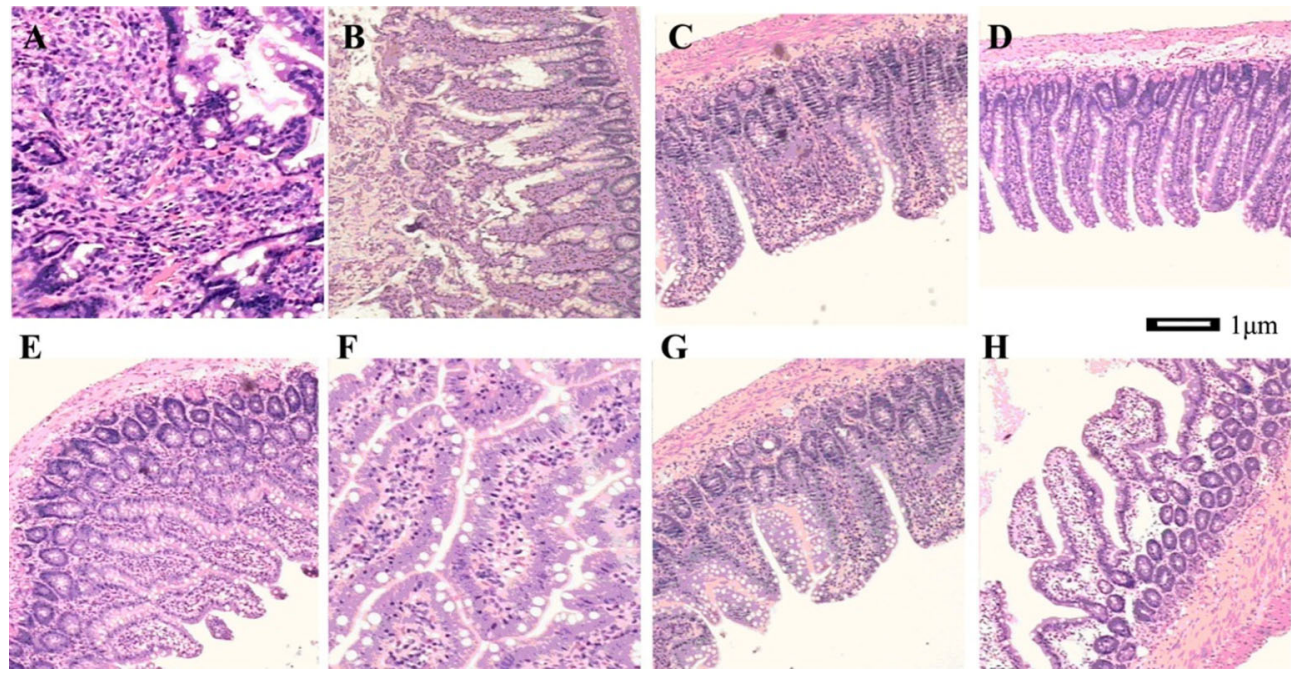

Figure 2. Morphometric analysis of the ileum. A, SAP group $(40 \times)$, interstitial ileum exhibited edema and inflammatory cell infiltration; blood vessels and lymph vessels were dilated and congested. B, SAP group $(40 \times)$, villus was edematous, highly shortened, disarranged and necrotic. Mucosal thickness became thin. $C, S A P+G$ group $(40 \times)$, villus epithelium proliferated and mucosal thickness increased. Inflammatory response was visible. $D, S A P+S$ group $(40 \times)$, inflammatory changes were decreased, and epithelial hyperplasia was observed, but active degree was less significant than that in the $S A P+G$ group. $E, S A P+G+S$ group $(40 \times)$, intestinal inflammatory response was mild, and microvilli were twisted and became longer. $F, S A P+G+S$ group $(100 \times)$, the cells were highly columnar, goblet cells were increased, and nuclei were overlapped significantly. $G, S A P+G+S$ group $(40 \times)$, villus was coarse and terminal was expanded. $H, S A P+G+S$ group $(40 \times)$, villus was twisted and branched. The images were obtained from at least three experiments. SAP: severe acute pancreatitis; NS: normal saline; G: growth hormone; S: somatostatin.

of male SD rats with TRIZOL reagent (Invitrogen). Following the manufacturer's instructions, $500 \mathrm{U}$ RNase inhibitor (RNAguard; Amersham Phamacia Biotech, USA) was added to the starting material, usually $500 \mathrm{mg}$ of pancreas tissue. RNA was stored at $-80^{\circ} \mathrm{C}$ until use. Reverse transcription reactions were performed as follows: $2 \mu \mathrm{L}$ total RNA $(1 \mu \mathrm{g} / \mu \mathrm{L}), 4 \mu \mathrm{L} 5 \times$ buffer, $2 \mu \mathrm{L}$

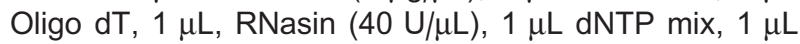
reverse transcriptase $(200 \mathrm{U} / \mu \mathrm{L})$. The total volume was $20 \mu \mathrm{L}$ with the addition of $9 \mu \mathrm{L}$ diethyl pyrocarbonate (DEPC)-treated distilled water. The procedure included: $42^{\circ} \mathrm{C}, 1 \mathrm{~h} ; 95^{\circ} \mathrm{C}, 10 \mathrm{~min}$. The cDNA was stored at $-20^{\circ} \mathrm{C}$ until use. The primers used in this study were HMGB-1 forward 5'-GAGATCCTAAGAAGCCGAGA-3', reverse 5'-CTTCСТCATCСТСTTCATCC-3'; GAPDH, forward 5'-CTCAAGATTGTCAGCAATGC-3', reverse 5'CAGGATGCCCTTTAGTGGGC-3'.

The $P C R$ reaction performed to assay the expression of HMGB1 was carried out as follows: $1 \mu \mathrm{L}$ cDNA, $2 \mu \mathrm{L}$ primers, $10 \mu \mathrm{L} 2 \times$ Tag PCR Master Mix, and $7 \mu \mathrm{L} 0.1 \%$ DEPC-water. The PCR procedure included $95^{\circ} \mathrm{C}$ for $5 \mathrm{~min}$; 35 cycles of $95^{\circ} \mathrm{C}$ for $1 \mathrm{~min}, 58^{\circ} \mathrm{C}$ for $30 \mathrm{~s}, 72^{\circ} \mathrm{C}$ for $30 \mathrm{~s}$ and $72^{\circ} \mathrm{C}$ for $10 \mathrm{~min}$. PCR products were separated by $2 \%$ agarose gel electrophoresis and visualized under ultraviolet light by ethidium bromide staining.

\section{Histological score of injured pancreas}

To directly observe the histological changes of tissues in each group, small pieces of pancreas tissues were harvested, fixed immediately in $4 \%$ phosphate buffered formalin for $24 \mathrm{~h}$, and then immersed in $75 \%$ ethanol. After paraffin embedding, 5- $\mu \mathrm{m}$ transverse sections were prepared and stained with HE for morphological observation. The images were recorded using an Olympus microscope (Japan).

Pancreatic tissues of 8 rats from each group were examined histologically under a light microscope; 20 random fields per slide were scored for edema, acinar necrosis, hemorrhage, and inflammation by an experienced pathologist according to Schmidt's standard method (20). The scoring criteria of pancreatic pathology are shown in Table 1.

\section{Measurement of cytokines and endotoxin}

After being treated for $24 \mathrm{~h}$, the blood of SAP rats in each group was collected and stored at $-20^{\circ} \mathrm{C}$ until analysis. The levels of IL-1 $1 \beta, \mathrm{IL}-6$ and TNF- $\alpha$ were measured by ELISA. Afterwards, endotoxin was measured using a chromogenic tripeptide assay.

\section{Statistical analysis}

Results are reported as means $\pm S D$. ANOVA was performed with the SPSS Windows 13.0 statistical analysis software (USA). $\mathrm{P}<0.05$ was considered to be significant. All experiments were replicated, with representative data shown. 


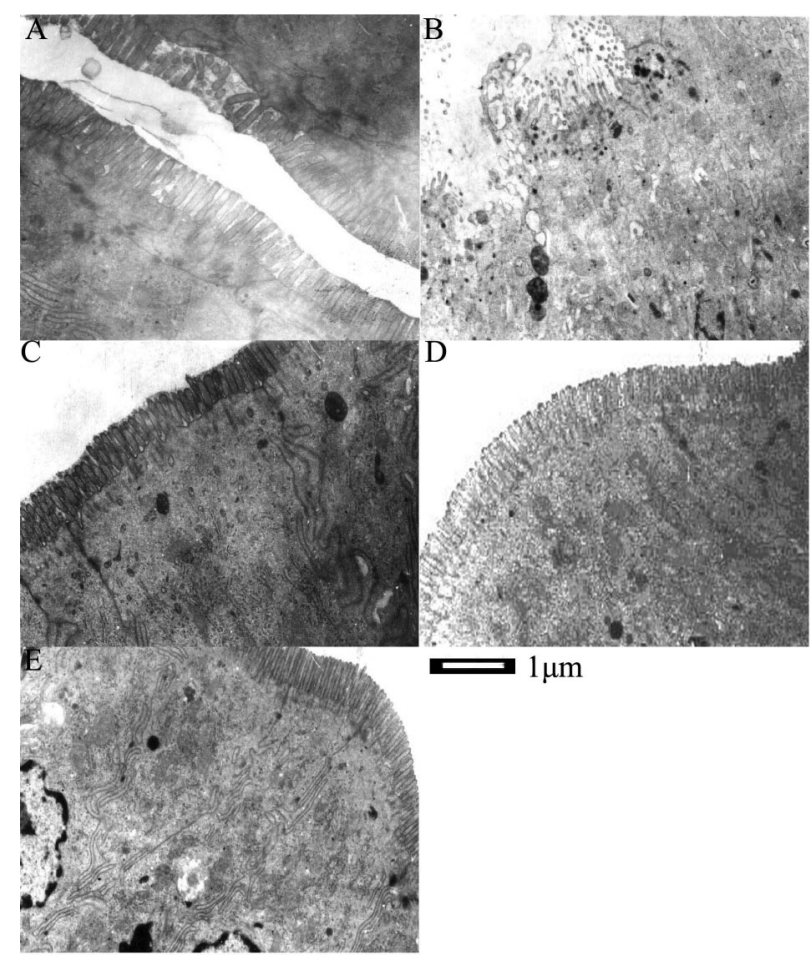

Figure 3. lleum mucosa at $24 \mathrm{~h}$ under transmission electron microscopy. $A$, Sham-operated group, the cells were dense; microvilli were arranged compactly and regularly, and organelles were integrated. $B$, SAP group, cell hydrops was obvious; intracellular particles were loose; organelles broke down; microvilli were disarranged; many necrotic cells were seen; and part of membrane damaged. $C$, $\mathrm{SAP}+\mathrm{G}$ group, most of the form and structure were normal; microvilli were slightly hypertrophic, and intercellular junction was integrated. $D, S A P+S$ group, intracellular matter was slightly loose, and organelles were still integrated. $E, S A P+S+G$ group, the microvilli were arranged orderly; structure was intact; organelle structure was complete and clear. The images were obtained from at least three experiments. SAP: severe acute pancreatitis; NS: normal saline; G: growth hormone; S: somatostatin.

\section{Results}

\section{Histological changes in pancreas tissues}

The histological scores of injured pancreas were obtained by blinded observers and indicated no obvious morphological changes (Figure 1C), necrosis, or hemorrhage in the sham-operated group. However, necrosis and hemorrhage were observed in the SAP group (Figure
1A). The interstitial pancreatic tissue was significantly wider and the lobular gap was increased. Infiltration of inflammatory cells and focal or patchy necrosis of pancreatic tissue were obvious by light microscopy, and the histological scores were significantly different from those of tissues from the sham-operated group $(\mathrm{P}<0.01$, Table 2). In the SAP+G+S group (Figure 1D), edema and inflammatory cell infiltration were found occasionally.

Table 3. Comparison of villus height and mucosal thickness in rat intestinal wall.

\begin{tabular}{lccc}
\hline Group & $\mathrm{n}$ & Villus height $(\mu \mathrm{m})$ & Mucosal thickness $(\mu \mathrm{m})$ \\
\hline Sham-operated & 6 & $61.722 \pm 5.615^{\#}$ & $92.403 \pm 4.514^{\#}$ \\
SAP+NS & 6 & $57.250 \pm 3.580^{\#}$ & $90.653 \pm 8.026^{\#}$ \\
SAP & 12 & $44.278 \pm 6.081^{*}$ & $70.833 \pm 10.217^{*}$ \\
SAP+G & 12 & $55.597 \pm 6.902^{\#}$ & $87.736 \pm 11.794^{\#}$ \\
SAP+S & 12 & $54.167 \pm 9.373^{\#}$ & $84.288 \pm 19.795^{\#}$ \\
SAP+G+S & 12 & $60.409 \pm 7.084^{\#}$ & $89.015 \pm 9.660^{\#}$ \\
\hline
\end{tabular}

Data are reported as means \pm SD. SAP: severe acute pancreatitis; NS: normal saline; G: growth hormone; $\mathrm{S}$ : somatostatin. ${ }^{*} \mathrm{P}<0.05$ compared to sham-operated group; ${ }^{\#} \mathrm{P}<0.05$ compared to SAP group (oneway ANOVA). 
A
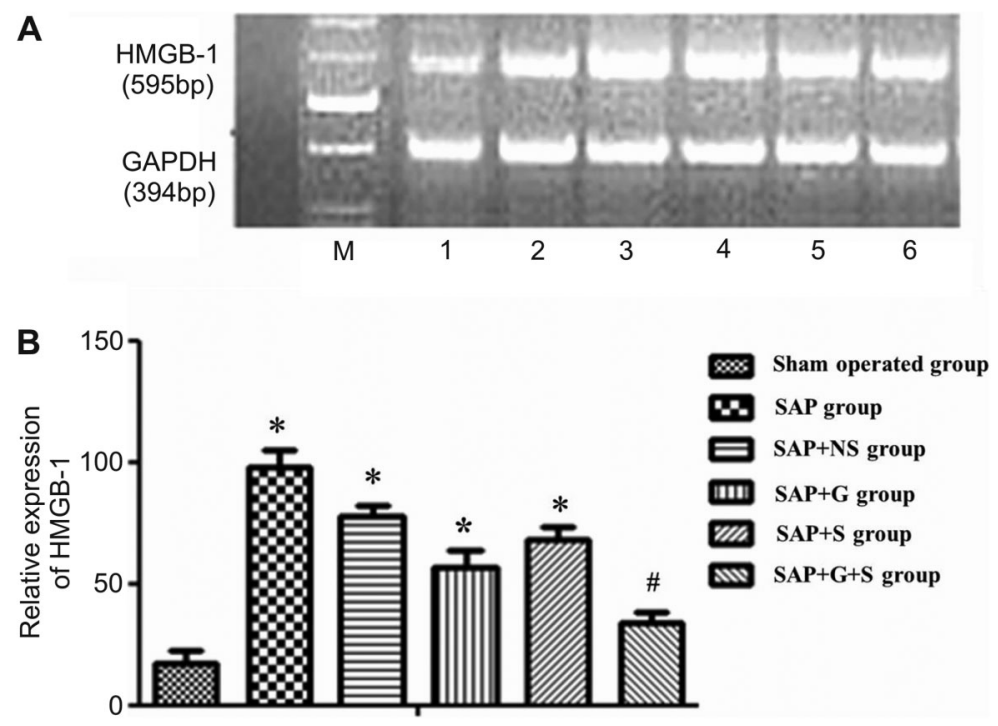

Figure 4. High-mobility group box 1 (HMGB-1) mRNA expression. A, HMGB-1 mRNA expression in all groups: M: marker; 1 : Sham-operated group; 2: SAP+NS group; 3: SAP group; 4: $S A P+G$ group; 5 : $S A P+S$ group; 6 : $\mathrm{SAP}+\mathrm{G}+\mathrm{S}$ group. $B, \mathrm{HMGB}-1 \mathrm{mRNA}$ expression at $24 \mathrm{~h}$. Data are reported as means \pm SD. SAP: severe acute pancreatitis; NS: normal saline; G: growth hormone; S: somatostatin. ${ }^{*} \mathrm{P}<0.05$, SAP, SAP + NS, SAP $+\mathrm{G}$, and $S A P+S$ groups compared to the sham-operated group. After being treated with $G+S$, the level of HMGB-1 was obviously decreased compared to the SAP group ( ${ }^{\#} \mathrm{P}<0.05$, one-way ANOVA).
In the $\mathrm{SAP}+\mathrm{G}$ and $\mathrm{SAP}+\mathrm{S}$ groups (Figure $1 \mathrm{E}$ and $\mathrm{F}$ ), inflammatory changes were still visible; the inflammatory response was decreased, and the resulting histological scores were changed significantly compared with those in SAP group ( $P<0.05$, see Table 2 and Figure 1).

\section{Histological changes in ileum tissues}

After HE staining, histological changes in ileum tissues as seen by light microscopy are shown in Figure 2. In the SAP group, interstitial congestion and edema, mild inflammatory cell infiltration, and mild interstitial hemorrhage were observed (Figure 2A). Villi were edematous; greatly shortened, disordered, and occasional necrotic villi were seen along with thinning of the mucosa (Figure 2B). In the $\mathrm{SAP}+\mathrm{G}$ group (Figure $2 \mathrm{C}$ ), cells in the epithelium of villi appeared to be proliferating actively, the mucosa



Figure 5. Serum endotoxin levels. The results are reported as means \pm SD. SAP: severe acute pancreatitis; NS: normal saline; G: growth hormone; S: somatostatin. The levels of endotoxin in SAP and SAP + NS groups were sharply elevated compared to those in the sham-operated group $\left({ }^{*} P<0.05\right)$. While in the $S A P+G, S A P+S$, and $S A P+G+S$ groups, the endotoxin was reduced significantly compared to the SAP group ( $P<0.05$ ), there was no significant difference compared to the shamoperated group (one-way ANOVA). was thickened, and the inflammatory response was still visible. In the SAP +S group (Figure 2D), inflammatory changes were decreased. Many lymphoid nodules, epithelial hyperplasia and germinal centers were found, but the degree of activity was significantly lower than that in the $S A P+G$ group. In the $S A P+G+S$ group (Figure $2 \mathrm{E}-\mathrm{H})$, the intestinal inflammatory response was decreased; villi were distorted, elongated and branched; epithelial cells were highly columnar; goblet cells were increased in number; and nuclei overlapped significantly.

Histological changes in ileum tissues as seen by electron microscopy are shown in Figure 3. In the shamoperated group (Figure $3 \mathrm{~A}$ ), the cells were dense, microvilli were orderly and arranged compactly, and organelles retained their integrity. In the SAP group (Figure 3B), cells were obviously swollen, intracellular particles were dispersed, organelles were damaged, and microvilli were disarranged. There were also many necrotic cells with partial membrane damage. While in the $S A P+G$ group (Figure $3 C$ ), the normal form and structure of most cells was maintained, microvilli were slightly enlarged, and intercellular junctions were intact. In the SAP +S group (Figure 3D), intracellular matter was slightly dispersed and organelles were still intact. In the $S A P+S+G$ group (Figure $3 \mathrm{E}$ ), the arrangement of microvilli was orderly, structural integrity was maintained, and organelle structures were also complete and clearly visible.

Measurements of villus height and mucosal thickness (Table 3) revealed that in the SAP group, the height of villi was significantly reduced, and the intestinal wall had become significantly thinner than in the sham-operated group (both $P<0.05)$. The degree of villus shortening in the $S A P+G$, $S A P+S$, and $S A P+G+S$ groups was less than in the SAP group $(P<0.05)$. In particular, the villi in the $S A P+G+S$ group were closer in height to that in the sham-operated group. 

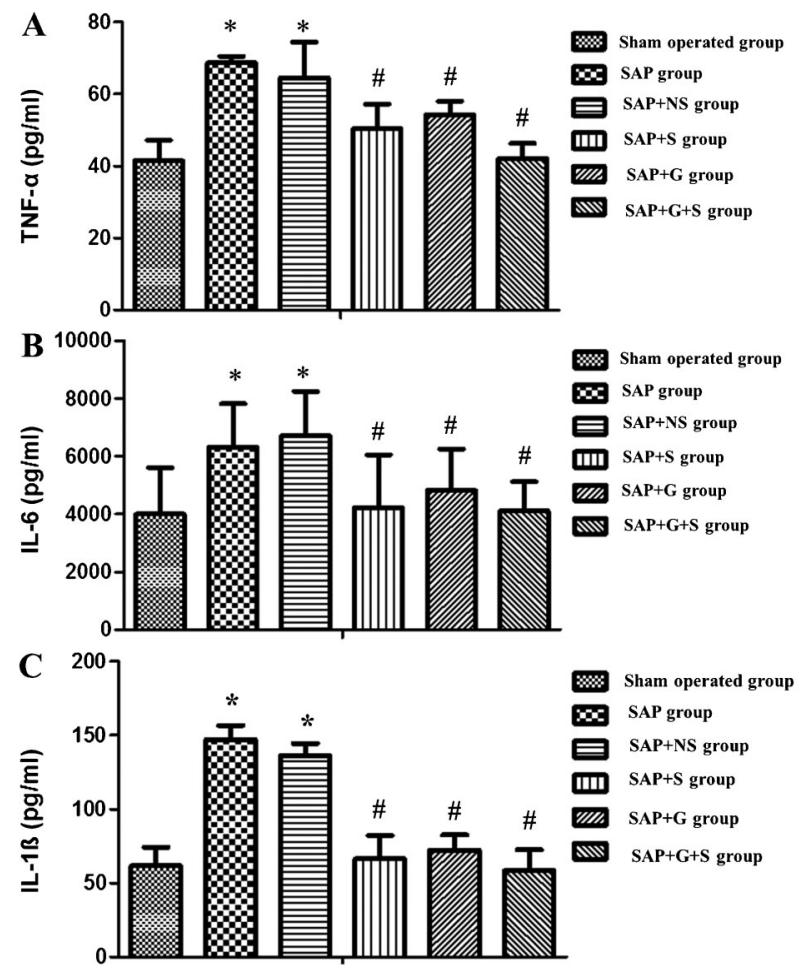

Figure 6. Serum cytokines TNF- $\alpha(A), \mathrm{IL}-6(B)$, and IL-1 $\beta(C)$ expression. The results are reported as means \pm SD. SAP: severe acute pancreatitis; NS: normal saline; G: growth hormone; $\mathrm{S}$ : somatostatin. The levels of TNF- $\alpha, \mathrm{IL}-6$, and IL- $1 \beta$ were all elevated in the SAP and SAP + NS groups compared to the sham-operated group $\left({ }^{*} \mathrm{P}<0.05\right)$. The levels in the $S A P+G$, $S A P+S$, and $S A P+G+S$ groups were decreased compared to the SAP group ( $\left.{ }^{\#} P<0.05\right)$. There were no significant differences in $S A P+G, S A P+S$, and $S A P+G+S$ groups compared to the sham-operated group (one-way ANOVA).

\section{HMGB-1 expression in pancreatic tissues}

RT-PCR revealed mRNA amplification products of HMGB-1 of $595 \mathrm{bp}$, and GAPDH mRNA amplification products of $394 \mathrm{bp}$ (Figure 4). In addition, after being treated for $24 \mathrm{~h}$, the mRNA expression of HMGB-1 was detected in every group. Significant differences existed between the SAP and sham-operated groups $(P<0.05)$ as well as the SAP + NS and sham-operated groups $(P<0.05)$. Compared with the SAP group, the expression of HMGB-1 was significantly down-regulated in the $S A P+G+S$ group $(P<0.05)$; but no obvious difference existed between the $\mathrm{SAP}+\mathrm{G}+\mathrm{S}$ and sham-operated groups.

\section{Endotoxin, IL-1 $\beta$, IL-6, and TNF- $\alpha$ levels}

The endotoxin levels in SAP and SAP + NS groups were significantly higher than in the sham-operated group $(P<0.05$, Figure 5). Additionally, in the SAP + S, SAP + G, and $S A P+G+S$ groups, the endotoxin levels were significantly lower than in the SAP or SAP + NS groups
$(P<0.05)$, but no significant difference was observed between the $S A P+G+S$ and sham-operated groups.

The IL-1 $\beta, I L-6$, and TNF- $\alpha$ levels in these groups are reported in Figure 6 . The levels of IL-1 $\beta$, IL-6, and TNF- $\alpha$ in the SAP and SAP + NS groups were significantly higher than those in the sham-operated group $(P<0.05)$. Furthermore, the IL-1 $\beta, \mathrm{IL}-6$, and TNF- $\alpha$ levels in the $S A P+S, S A P+G$ and $S A P+G+S$ groups were significantly lower than those in the SAP and SAP + NS groups $(\mathrm{P}<0.05)$.

\section{Comparison of survival rates in rats}

Kaplan-Meier analysis was used to compare the survival rates in each group over a period of 7 days (Figure 7). The 7-day survival rate was $100 \%$ in the shamoperated group, while in the SAP group, six rats had died at $24 \mathrm{~h}$, and all rats were dead at $48 \mathrm{~h}$ giving a 7-day survival rate of $0 \%$. In the SAP + NS group, the 7 -day survival rate was also $0 \%$. The differences in survival rates observed in both SAP and SAP + NS groups compared with that in the sham-operated group were significant $(P<0.01)$. In the $S A P+S$, SAP $+G$, and $S A P+G+S$ groups, the 7-day survival rates were 60 , 30 , and $90 \%$, respectively. The differences in survival rate observed in $S A P+S$, SAP $+G$, and $S A P+G+S$ groups compared with that in the SAP group, especially in the $\mathrm{SAP}+\mathrm{S}+\mathrm{G}$ group, were all significant $(\mathrm{P}<0.05)$.

\section{Discussion}

SAP is a serious, potentially life-threatening type of acute pancreatitis that follows a severe course in approximately $25 \%$ of patients, with local and/or systemic complications leading to a high mortality rate (21). The complications occurring in SAP may be both local (pancreatic necrosis and pseudocyst) and systemic (organ dysfunction, shock, and acute respiratory distress syndrome) (22).

During SAP, increasing permeability of gastrointestinal mucosa occurs in its early phase and facilitates bacterial/ endotoxin translocation (23). Normally, the gastrointestinal tract absorbs nutrients and acts as a barrier to exclude luminal bacteria from the internal environment (24). However, SAP-induced increase of intestinal permeability, which promotes bacterial and endotoxin translocation, leads to sepsis and MODS (25). It has been suggested that stabilization of intestinal integrity can reduce pancreatic infections in experimental and clinical pancreatitis (26).

In this study, the rats with SAP showed an increased inflammatory response of the ileum compared with the sham-operated group, and the subsequent endotoxin level was significantly elevated in our experimental SAP model. In fact, extensive inflammatory cell infiltration and focal or patchy necrosis of pancreas existed in the SAP model (27), and inflammatory cell infiltration is known to facilitate the release of endotoxin (23). This is consistent 


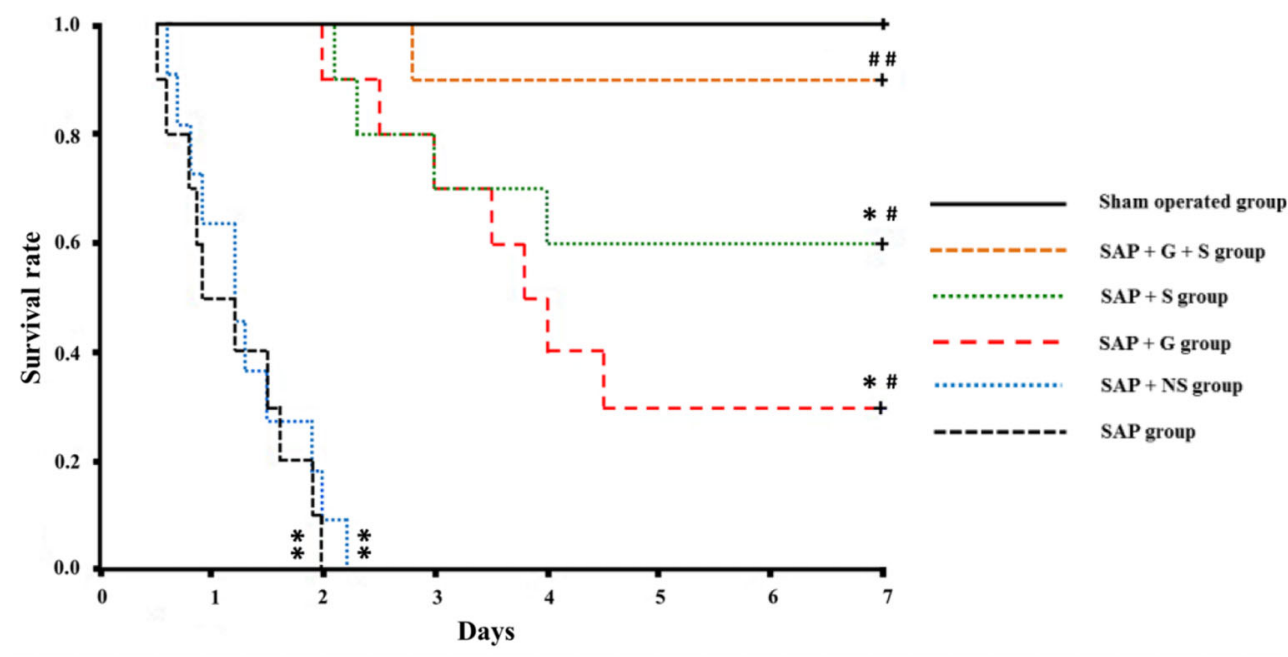

Figure 7. Survival rate. Survival rates of rats are described with different symbols and colors. The results showed no death in the shamoperated group, and the survival rates of rats in the SAP and SAP + NS groups were significantly different from that in the shamoperated group $(P<0.01)$. SAP $+G, S A P+S$, and $S A P+G+S$ groups had significantly different survival rates compared to the SAP group $\left(\mathrm{P}<0.05, \mathrm{P}<0.05\right.$, and $\mathrm{P}<0.01$, respectively). ${ }^{*} \mathrm{P}<0.05$ and ${ }^{* *} \mathrm{P}<0.01$ compared to the sham-operated group; ${ }^{\#} \mathrm{P}<0.05$ and \#\# $\mathrm{P}<0.01$ compared to the SAP group (one-way ANOVA). SAP: severe acute pancreatitis; NS: normal saline; G: growth hormone; S: somatostatin.

with the observed increase in inflammatory cell infiltration and up-regulated endotoxin level.

In addition, the humoral mediators released by excessive activation of macrophages/monocytes and neutrophils have been reported to lead to remote organ injury (28). Here, the expression of HMGB1 and the levels of inflammatory cytokines in serum, including TNF- $\alpha$, IL$1 \beta$, and IL-6, were increased significantly in the pancreas of rats with SAP compared with those in sham-operated rats. HMGB1 was recently identified as a late mediator of lethal systemic inflammation (29), which contributes to its potential as a target for the development of antiinflammatory treatments. In addition, HMGB1 has been shown to be a downstream cytokine of early-phase inflammatory cytokines such as TNF and IL-1, which are involved in SAP-associated SIRS (1). Therefore, it is likely that HMGB1 is produced and released by damaged organs in SAP. Another study also found that the modulation of HMGB1 and other inflammatory cytokine responses was associated with a reduction in the severity of SAP by ethyl pyruvate, which may play a therapeutic role in liver inflammation in this SAP model (30). Furthermore, in acute pancreatitis, proinflammatory cytokines, such as IL-1, IL- 6 , and TNF- $\alpha$, are produced within the pancreas and subsequently within distant organs, and the severity of acute pancreatitis is well correlated with the levels of these cytokines $(31,32)$. That evidence is consistent with our results, suggesting that overexpression of HMGB1, TNF- $\alpha, \mathrm{IL}-1 \beta$, and IL- 6 may be related to the intestinal damage occurring in experimental SAP, and these gene products could be potential markers to diagnose the progress of SAP.

Moreover, effects of growth hormone and somatostatin on SAP were detected in this study. Administration of growth hormone and somatostatin to the rats with SAP resulted in significant reductions of HMGB1, IL-1 $\beta, I L-6$, TNF- $\alpha$ and endotoxin levels as well as in the alleviation of histological changes. In previous investigations, growth hormone has been reported $(15,26)$ to alleviate acute necrotizing pancreatitis (taurocholate model) in rats, and the mechanism of the protective function of growth hormone in acute pancreatitis might be related to the improvement of intestinal barrier permeability through down-regulation of apoptosis in intestinal cells (33). Our results are in agreement with this in demonstrating that treatment with growth hormone can inhibit the release of TNF- $\alpha$ in SAP rats and humans to some extent $(15,34)$. Additionally, in this study, both growth hormone and somatostatin reduced the mortality of SAP, which is in line with previous studies showing that the mortality and local complications of acute pancreatitis (35) declined after treatment with somatostatin (36). Somatostatin treatment has also been associated with a slight reduction in the need for surgery due to local complications (37). Meanwhile, in this study, the effects of somatostatin in SAP rats were similar to growth hormone. Both attenuated levels of HMGB1, IL-1 $\beta$, IL-6, TNF- $\alpha$, and endotoxin, as well as the inflammatory response in pancreas and ileum tissue. Mortality of SAP rats was also lower in those treated with growth hormone and somatostatin. However, an inhibitory effect of somatostatin on growth hormone release has been reported by Arimura et al. (38). Hence, the clinical 
effects of growth hormone and somatostatin on SAP need to be further confirmed. Their specific functions in SAP, and whether they are related to a synergistic effect require further examination.

In conclusion, this study showed that both growth hormone and somatostatin could attenuate the inflammatory response in pancreas and ileum tissues in SAP model rats, and significantly decrease HMGB1, TNF- $\alpha$, IL$1 \beta$, IL-6 and endotoxin levels. Moreover, the improvement of $G+S$ on the severity of acute pancreatitis and the survival rate of SAP rats was greater than only treating with growth hormone or somatostatin. However, further studies should be performed to evaluate protein and

\section{References}

1. Yuan $\mathrm{H}$, Jin X, Sun J, Li F, Feng Q, Zhang C, et al. Protective effect of HMGB1 a box on organ injury of acute pancreatitis in mice. Pancreas 2009; 38: 143-148, doi: 10.1097/MPA.0b013e31818166b4.

2. Hayden P, Wyncoll D. Severe acute pancreatitis. Curr Anaesth Crit Care 2008; 19: 1-7.

3. Ammori BJ. Role of the gut in the course of severe acute pancreatitis. Pancreas 2003; 26: 122-129, doi: 10.1097/ 00006676-200303000-00006.

4. Lankisch PG, Lerch MM. Pharmacological prevention and treatment of acute pancreatitis: where are we now? Dig Dis 2006; 24: 148-159, doi: 10.1159/000090318.

5. Buter A, Imrie CW, Carter CR, Evans S, McKay CJ. Dynamic nature of early organ dysfunction determines outcome in acute pancreatitis. Br J Surg 2002; 89: 298-302.

6. Yasuda T, Ueda T, Takeyama Y, Shinzeki M, Sawa H, Nakajima $T$, et al. Significant increase of serum highmobility group box chromosomal protein 1 levels in patients with severe acute pancreatitis. Pancreas 2006; 33: 359-363, doi: 10.1097/01.mpa.0000236741.15477.8b.

7. Bustin M, Reeves R. High-mobility-group chromosomal proteins: architectural components that facilitate chromatin function. Prog Nucleic Acid Res Mol Biol 1996; 54: 35-100, doi: 10.1016/S0079-6603(08)60360-8.

8. Park JS, Arcaroli J, Yum HK, Yang H, Wang H, Yang KY, et al. Activation of gene expression in human neutrophils by high mobility group box 1 protein. Am J Physiol Cell Physiol 2003; 284: C870-C879, doi: 10.1152/ajpcell.00322.2002.

9. Scaffidi $P$, Misteli T, Bianchi ME. Release of chromatin protein HMGB1 by necrotic cells triggers inflammation. Nature 2002; 418: 191-195, doi: 10.1038/nature00858.

10. Zhang ZW, Zhang QY, Zhou MT, Liu NX, Chen TK, Zhu YF, et al. Antioxidant inhibits HMGB1 expression and reduces pancreas injury in rats with severe acute pancreatitis. Dig Dis Sci 2010; 55: 2529-2536, doi: 10.1007/s10620-0091073-0.

11. Luan ZG, Zhang H, Ma XC, Zhang C, Guo RX. Role of highmobility group box 1 protein in the pathogenesis of intestinal barrier injury in rats with severe acute pancreatitis. Pancreas 2010; 39: 216-223, doi: 10.1097/MPA.0b013e $3181 \mathrm{bab} 5 \mathrm{c} 5$.

12. Luan ZG, Ma XC, Zhang H, Zhang C, Guo RX. Protective effect of ethyl pyruvate on pancreas injury in rats with plasma levels of HGMB1 to verify the protective effects of growth hormone and somatostatin on SAP, elucidate the role of HMGB1 in SAP, and explore whether the combination of growth hormone and somatostatin can improve the survival rate of SAP patients clinically. Moreover, the possible mechanisms of growth hormone and somatostatin on SAP need to be further investigated.

\section{Acknowledgements}

Research supported by a grant from the Science and Technology Commission of Shanghai Municipality (\#11nm0503900).

severe acute pancreatitis. J Surg Res 2013; 181: 76-84.

13. Felderbauer $P$, Muller $C$, Bulut K, Belyaev O, Schmitz F, Uhl $W$, et al. Pathophysiology and treatment of acute pancreatitis: new therapeutic targets - a ray of hope? Basic Clin Pharmacol Toxicol 2005; 97: 342-350, doi: 10.1111/j.17427843.2005.pto_274.x.

14. Han X, Sosnowska D, Bonkowski EL, Denson LA. Growth hormone inhibits signal transducer and activator of transcription 3 activation and reduces disease activity in murine colitis. Gastroenterology 2005; 129: 185-203, doi: 10.1053/ j.gastro.2005.05.018.

15. Andiran N, Yordam N. TNF-alpha levels in children with growth hormone deficiency and the effect of long-term growth hormone replacement therapy. Growth Horm IGF Res 2007; 17: 149-153, doi: 10.1016/j.ghir.2007.01.002.

16. Jaworek J, Leja-Szpak A, Dembinski A, Tomaszewska R, Szklarczyk J, Kot M, et al. Involvement of sensory nerves in the protective effect of growth hormone on acute pancreatitis. Growth Horm IGF Res 2009; 19: 517-522, doi: 10. 1016/j.ghir.2009.06.001.

17. Ferone D, van Hagen PM, Semino C, Dalm VA, Barreca A, Colao $A$, et al. Somatostatin receptor distribution and function in immune system. Dig Liver Dis 2004; 36 (Suppl 1): S68-S77, doi: 10.1016/j.dld.2003.11.020.

18. Tang WF, Wan MH, Zhu L, Chen GY, Xia Q, Huang X. [Immuno-modulatory effect of somatostatin combined with traditional Chinese medicine on severe acute pancreatitis at early stage: a randomized control trial]. Zhong Xi Yi Jie He Xue Bao 2005; 3: 103-107, doi: 10.3736/jcim20050206.

19. Li ZD, Ma QY, Wang CA. Effect of resveratrol on pancreatic oxygen free radicals in rats with severe acute pancreatitis. World J Gastroenterol 2006; 12: 137-140.

20. Schmidt J, Rattner DW, Lewandrowski K, Compton CC, Mandavilli U, Knoefel WT, et al. A better model of acute pancreatitis for evaluating therapy. Ann Surg 1992; 215: 4456, doi: 10.1097/00000658-199201000-00007.

21. Piascik M, Rydzewska G, Milewski J, Olszewski S, Furmanek M, Walecki J, et al. The results of severe acute pancreatitis treatment with continuous regional arterial infusion of protease inhibitor and antibiotic: a randomized controlled study. Pancreas 2010; 39: 863-867, doi: 10.1097/ MPA.0b013e3181d37239.

22. Su MS, Lin MH, Zhao QH, Liu ZW, He L, Jia N. Clinical 
study of distribution and drug resistance of pathogens in patients with severe acute pancreatitis. Chin Med J 2012; 125: 1772-1776.

23. Ammori BJ, Leeder PC, King RF, Barclay GR, Martin IG, Larvin $M$, et al. Early increase in intestinal permeability in patients with severe acute pancreatitis: correlation with endotoxemia, organ failure, and mortality. J Gastrointest Surg 1999; 3: 252-262, doi: 10.1016/S1091-255X(99)800 67-5.

24. Braga M, Gianotti L, Gentilini O, Liotta S, Di Carlo V. Feeding the gut early after digestive surgery: results of a nine-year experience. Clin Nutr 2002; 21: 59-65, doi: 10.1054/clnu.2001.0504.

25. Juvonen PO, Alhava EM, Takala JA. Gut permeability in patients with acute pancreatitis. Scand J Gastroenterol 2000; 35: 1314-1318.

26. Wang X, Wang B, Wu J, Wang G. Beneficial effects of growth hormone on bacterial translocation during the course of acute necrotizing pancreatitis in rats. Pancreas 2001; 23: 148-156, doi: 10.1097/00006676-200108000-00005.

27. Van Laethem JL, Marchant A, Delvaux A, Goldman M, Robberecht $\mathrm{P}$, Velu $\mathrm{T}$, et al. Interleukin 10 prevents necrosis in murine experimental acute pancreatitis. Gastroenterology 1995; 108: 1917-1922, doi: 10.1016/0016-5085(95)901582.

28. Sawa H, Ueda T, Takeyama $Y$, Yasuda $T$, Shinzeki $M$, Nakajima T, et al. Blockade of high mobility group box-1 protein attenuates experimental severe acute pancreatitis. World J Gastroenterol 2006; 12: 7666-7670.

29. Wang H, Yang H, Czura CJ, Sama AE, Tracey KJ. HMGB1 as a late mediator of lethal systemic inflammation. Am J Respir Crit Care Med 2001; 164: 1768-1773.

30. Luan ZG, Zhang H, Ma XC, Zhang C, Guo RX. Therapeutic treatment with ethyl pyruvate attenuates the severity of liver injury in rats with severe acute pancreatitis. Pancreas 2012; 41: 729-737.

31. Norman JG, Fink GW, Denham W, Yang J, Carter G, Sexton C, et al. Tissue-specific cytokine production during experimental acute pancreatitis. A probable mechanism for distant organ dysfunction. Dig Dis Sci 1997; 42: 1783-1788, doi: $10.1023 / \mathrm{A}: 1018886120711$.

32. Norman J. The role of cytokines in the pathogenesis of acute pancreatitis. Am J Surg 1998; 175: 76-83.

33. Wang X, Wang B, Wu K, Xu M, Gong Z. Growth hormone downregulated the excessive apoptosis of ileal intestinal epithelial cells in rats during the early course of acute necrotizing pancreatitis. Pancreas 2002; 25: 205-209, doi: 10.1097/00006676-200208000-00016.

34. An Y, Xiao YB. Growth hormone prevents acute liver injury induced by cardiopulmonary bypass in a rat model. $J$ Thorac Cardiovasc Surg 2007; 134: 342-350, doi: 10.1016/ j.jtcvs.2007.02.036.

35. Choi TK, Mok F, Zhan WH, Fan ST, Lai EC, Wong J. Somatostatin in the treatment of acute pancreatitis: a prospective randomised controlled trial. Gut 1989; 30: 223-227, doi: 10.1136/gut.30.2.223.

36. Buchler MW, Binder M, Friess $\mathrm{H}$. Role of somatostatin and its analogues in the treatment of acute and chronic pancreatitis. Gut 1994; 35: S15-S19, doi: 10.1136/gut.35 3 Suppl.S15.

37. Planas M, Perez A, Iglesia R, Porta I, Masclans JR, Bermejo B. Severe acute pancreatitis: treatment with somatostatin. Intensive Care Med 1998; 24: 37-39, doi: 10.1007/s001340050512.

38. Arimura A, Sato H, Dupont A, Nishi N, Schally AV. Somatostatin: abundance of immunoreactive hormone in rat stomach and pancreas. Science 1975; 189: 1007-1009, doi: $10.1126 /$ science. 56779 . 